\title{
INVENTARISASI JENIS-JENIS TANAMAN PENGHASIL NEKTAR DAN POLEN SEBAGAI PAKAN LEBAH MADU Apis mellifera DI KECAMATAN KAIRATU KABUPATEN SERAM BAGIAN BARAT
}

\author{
Dominggus de Lima ${ }^{1}$, J.S.A. Lamerkabel ${ }^{2}$, Ingrid Welerubun ${ }^{3}$ \\ ${ }^{1}$ Jurusan Peternakan Fakultas Pertanian, Universitas Pattimura \\ Jln. Ir. M. Putuhena, Kampus Poka, Ambon 97233 \\ ${ }^{2}$ Jurusan Budidaya Pertanian Fakultas Pertanian, Universitas Pattimura \\ Jln. Ir. M. Putuhena, Kampus Poka, Ambon 97233 \\ ${ }^{3}$ Program Studi Peternakan PSDKU Universitas Pattimura Di Kabupaten Maluku Barat Daya \\ Kampus Tiakur, Tiakur \\ *Email : dominggus.delima@faperta.unpatti.ac.id
}

\begin{abstract}
ABSTRAK
Penelitian ini bertujuaan untuk mengetahui jenis-jenis tanaman dan kerapatan populasi tanaman, jenis-jenis tanaman penghasil pollen, nektar dan sisiran sarang yang terisi bee bread (bee pollen yang ada di dalam sel-sel sisiran sarang).Variabel yang diamati meliputi jenis-jenis tanaman dan kerapatan populasi tanaman, jenis-jenis tanaman penghasil pollen, nectar dan sisiran yang terisi bee bread. Metode yang digunakan adalah metode survey pada empat lokasi sampel peternakan lebah madu di kecamatan Kairatu kabupaten Maluku Tengah. Hasil penelitian menunjukan bahwa jenis tanaman yang terdapat pada empat lokasi peternakan lebah madu adalah tanaman hias antara lain: bunga kamboja, bunga Osaka, bunga bougenvil, tanaman perkebunan antara lain: kelapa (Cocos mufifera), pala (Myristisca frogranas houtt), aren (Arenga pinnata), kakao (Theobroma cacao), cengkih (Syzygiumaromatioum). Tanaman buah-buahan antara lain: jambu biji (Psidium guajava), jambu mete (Arnacidium occidentale), rambutan (Nephelium lappaceum), mangga (mangifera indica), pisang (Musa paradisiacal) dan langsat (Lansium domesticium). Dari empat lokasi peternakan lebah madu, Negeri yang memiliki nilai kerapatan tertinggi adalah Dusun Kawatu, selanjutnya di ikuti dengan Negeri Hatusua, Negeri Waehatu dan Negeri Kamarian, Dusun Kawatu di samping memiliki kerapatan tinggi, namun di Dusun Kawatu populasi tanaman kurang dibandingkan dengen tiga Negeri yang lain. Jumlah sisiran yang terisi bee bread terbanyak adalah Negeri Kamarian selanjutnya di ikuti Negeri Hatusua, Dususn Kawatu dan Negeri Waehatu.
\end{abstract}

Kata kunci: Jenis tanaman, pollen, bee bread, Apis mellifera

\section{SOME OF POLLEN PLANTS AS FEED SOURCE OF Apis mellifera IN KAIRATU DISTRICT WEST SERAM REGENCY}

\begin{abstract}
ABSTRAK
The aim of this research was to determine the kinds of pollen producer plants, its population density and the number of cells contained bee bread (pollen) at bee nest. The observed variables were kinds of plants in general and its density, pollen producer plants, number of cells contained bee breed (pollen). Method used was survey techniques which conducted in four bee farms. The farms were naturally rich of some flowering plants such as Cambodia, asoka, bougainville; and some horticulture plants such as coconut Cocos mufifera), nutmeg (Myristisca frogranas houtt), palm (Arenga pinnata), cacao (Theobroma cacao), clove (Syzygiumaromatioum); some fruits plants such as guava(Psidium guajava), nut guava(Arnacidium occidentale), ambutan(Nephelium lappaceum), mango(mangifera indica), banana(Musa paradisiacal), langsat(Lansium domesticium). From the four bee farms chosen, there was revealed that Dusun Kawatu has the highest plant density, followed by respectively Negeri Hatusua, Negeri Waehatu and Negeri Kamarian. Also, Dusun Kawatu has more pollen producer plant varieties in comparison to the other three Negeri/ Dusun(s). However, bee farm in Negeri Kamarian has more number of cell contained pollen than other farms; followed respectively by bee farms in Negeri hatusua, Dusun Kawatu and Negeri Waehatu.
\end{abstract}

Key words: Plant varieties, pollen, bee braed, Apis mellifera 


\section{PENDAHULUAN}

Budidaya lebah madu sudah lama menjadi bagian dari kehidupan masyarakat, khususnya yang tinggal di pedesaan sekitar hutan. Namun seiring dengan semakin berkurangnya tutupan kawasan hutan, ketersediaan tanaman pakan lebah juga semakin berkurang. Penurunan ketersediaan tanaman pakan telah menjadi permasalahan utama dalam budidaya lebah madu. Setiawan dkk. (2016), menyatakan bahwa kelangkaan sumber pakan merupakan permasalahan yang menduduki urutan pertama. Lebah madu dan tanaman berbunga memiliki hubungan yang saling menguntungkan yaitu tanaman sebagai penyediaan pakan lebah berupa nektar dan polen, sedangkan lebah madu melakukan proses polinasi tanaman tersebut.

Ketersediaan tanaman pakan lebah (bee forages) dan kelimpahan sumber pakan merupakan faktor utama yang menentukan keberhasilan usaha perlebahan. Hal ini disebabkan karena perkembangan dan produktivitas koloni lebah sangat tergantung pada ketersediaan pakan, yaitu nektar dan polen (tepung sari) yang dihasilkan oleh tanaman (Walji, 2001). Masa pembungaan tanaman pada umumnya bersifat musiman. Kondisi ini menyebabkan lebah madu mengalami kelangkaan pangan pada saat tertentu, karena makanan lebah, khususnya polen (tepung sari), hanya dapat diperoleh dari bunga. Apabila masa pembungaan pendek, selain produksi madu sedikit, juga dapat menyebabkan koloni pindah. Sebaliknya, apabila masa pembungaan tanaman cukup panjang maka produksi madu yang dihasilkan lebih tinggi. Oleh karena itu tanaman pakan harus tersedia dalam jumlah yang cukup dan masa pembungaannya berkesinambungan agar koloni lebah berproduksi optimal.

Pakan merupakan kebutuhan yang sangat penting bagi kelanjutan peternakan lebah madu. Kekurangan pakan merupakan masalah yang sangat serius dan dapat menghambat perkembangan usaha peternakan lebah madu yang berdampak pada penurunan produksi madu, polen dan royal jeli sehingga menurunkan pendapatan petani lebah. Agussalim dkk. (2017), kekurangan pakan dapat menyebabkan koloni lebah madu menjadi lemah dari segi jumlah lebah pekerja sedikit, produksi madu, polen dan royal yeli rendah, produktifitas lebah ratu menurun karena kekurangan pasokan pakan nectar dan polen sebagai sumber karbohidrat dan protein.

Produk lebah madu telah lama dikenal oleh masyarakat Maluku sebagai sumber makanan alami ataupun dipakai sebagai obat tradisional, namun usaha untuk mengetahui jenis-jenis lebah madu, tanaman penghasil pakan lebah madu dan bagaimana cara memeliharanya agar dapat menghasilkan madu yang dapat dipanen lebih banyak secara berkelanjutan belum banyak dilakukan.

Kecamatan Kairatu Kabupaten Seram Bagian Barat telah banyak melakukan berbagai usaha dalam rangka meningkatkan produktivitas peternakan, baik ternak ruminansia maupun ternak non ruminansia dengan melakukan berbagai pembinaan melalui dinas atau instansi terkait, disamping itu peluang untuk pengembangan lebah madu di Kecematan Kairatu masih sangat luas. Pengembangan lebah madu sangat tergantung dari keadaan alam sekitar areal padang pengembalaan terutama jenis tanaman yang mampu menyediakan pakan untuk kehidupan lebah madu baik berupa nektar maupun pollen yang banyak terdapat pada tanaman perkebunan, tanaman buah-buahan, tanaman pangan dan sebagainya.

Wilayah Kecamatan Kairatu memiliki tiga jenis lebah madu yaitu Apis cerana, Apis mellifera dan Trigona spp (Lamerkabel, 2010), juga terdapat hutan alam dengan beraneka jenis tanaman, perkebunan, tanaman pangan dan tanaman buah-buahan yang dapat menyediakan nektar dan pollen sebagai pakan lebah madu serta dapat berfungsi sebagai habitat yang sangat ideal untuk usaha peternakan lebah madu tersebut. Kajian ini bertujuan untuk mengetahui jenis-jenis tanaman dan kerapatan populasi tanaman, jenis-jenis tanaman penghasil nektar dan pollen, sisiran sarang yang terisi bee bread (bee pollen yang ada di dalam sel-sel sisiran sarang pada lokasi usaha lebah madu Apis mellifera di Kecamatan Kairatu Kabupaten Seram Bagian Barat.

\section{BAHAN DAN METODE}

Penelitian dilaksanakan di Kecamatan Kairatu, Kabupaten Seram Bagian Barat berlokasi pada 4 (empat) desa/negeri sampel yaitu Waehatu, Hatusua, Kawatu, dan Kamariang. Pelaksanaan penelitian berlangsung selama 3 (tiga) bulan.

Metode yang digunakan dalam penelitian ini adalah metode survey pada empat lokasi peternakan lebah madu untuk dapat mengetahui jenis-jenis tanaman dan kerapatan populasi tanaman, jenis-jenis tanaman penghasil nectar dan polen, serta sisiran sarang yang terisi bee bread.

Variabel yang diamati dalam penelitian ini meliputi :

a) Jenis Tanaman.

Untuk mengetahui jenis tanaman yang terdapat di sekitar areal peternakan lebah madu maka dilakukan inventarisasi semua jenis tanaman yang terdapat pada areal penggembalaan tersebut dengan jarak 2 (dua) km dari kotak (stup) lebah madu.

b) Kerapatan Populasi Tanaman.

Untuk menghitung kerapatan populasi tanaman digunakan petunjuk Arifin (1994). Teknik pengambilan data yang dibuat pada area penelitian berbentuk bujur sangkar dan di buat dalam petakpetak kontinyu 20 x $20 \mathrm{~m}^{2}$. Tahapannya adalah sebagai berikut: (1) ubinan pertama dengan luas $400 \mathrm{~m}^{2}$ ditentukan secara acak, sedangkan ubinan kedua diambil secara kontinyu dari ubinan pertama dan seterusnya ; (2) dilakukan pendataan semua 
jenis flora pakan yang ada pada masing-masing ubinan dengan jumlah individunya ; (3) untuk mengetahui tingkat kerapatan dan frekuensi dari masing-masing jenis flora pakan digunakan rumus Soerianegara dan Andry (1998) sebagai berikut:

1. Kerapatan $=\frac{\text { Jenis Individu }}{\text { Luas } \text { sampel }}$

2. Kerapatan relatif $(\%)=\frac{\text { Kerapatan suatu spesies }}{\text { Kerapatan seluruh spesies }} \times 100 \%$

3. Frekuensi $=\frac{\text { Jumlah petak menurut spesies }}{\text { Jumlah seluruh petak }}$

4. Frekuensi relatif $(\%)=\frac{\text { Frekuensi suatu spesies }}{\text { Frekuensi seluruh spesies }} \times 100 \%$

5. Indeks nilai penting $=$ kerapatan relatif + frekuensi relatif

c) Jenis-Jenis Tanaman Penghasil Nektar dan Pollen. Untuk mengetahui tanaman-tanaman penghasil pollen maka dilakukan pengamatan terhadap lebah madu yang mengunjungi bunga pada tanamantanaman yang berada di masing-masing lokasi. Waktu pengamatan yaitu mulai dari jam 05.30 pagi sampai 12.30 siang dan pada pukul 14.00 sampai 17.45 pada sore hari. Untuk mengidentifikasi nektar dan polen dilakukan dengan cara, mengambil satu atau dau sampel bunga kemudian memeriksa ketersediaan nektarnya. Pengecekan dilakukan dengan membuka mahkota bunga kemudian memeriksa cairan nektar pada bagian dasar bunga. Sedangkan untuk memeriksa polen dilakukan pemeriksaan pada bagian kepala sari dan anternya. Polen berbentuk serbuk atau tepung dan umumnya berwarna berwarna kuning.

d) Sisiran yang terisi bee bread

Untuk mengetahui jumlah sisiran yang terisi bee bread dilakukan pangamatan terhadap setiap sisiran sarang di dalam sepuluh kotak yang terdapat pada masing-masing lokasi. Pengamatan dilakukan selama sepuluh hari untuk yiap lokasi desa/negeri sampel.

Data yang diperoleh ditabulasi dan dianalisis secara deskriptif sesuai tujuan penelitian.

\section{HASIL DAN PEMBAHASAN}

\section{Jenis Tanaman}

Hasil pengamatan pada empat lokasi penelitian ditemukan jenis-jenis tanaman, yaitu tanaman buahbuahan, tanaman hias dan tanaman perkebunan. Tanaman buah-buahan berupa jambu air (Syzgium aqueum), jambu biji (Psidium guajava), kecapi (Sondoricium koetjtie), jeruk (Citrus aurantifolia), pisang (Musa paradisiaca), mangga (Mangifera indica), langsat (Lansiu domesticium), kwuini (Mangifera odorata), belimbing (Averroa carambola), aren (Averroa carambola), gandaria (Bouea macropaylla), rambutan (Nephelium Lappaceum), alpokat (Persea Americana), nangka (Artocarpus heterophyllus) dan tomi-tomi (nama lokal).

Tanaman hias yang terdapat pada lokasi pengembalaan lebah antara lain bunga bougenville, bunga asoka, dan bunga kamboja. Sedangkan yang termasuk dalam tanaman perkebunan antara lain cengkih, pala, kakao, kelapa dan jambu biji (Tabel 1). Tanaman- tanaman tersebut merupakan sumber pakan (nektar dan polen) bagi lebah madu. Menurut Sihombing (2005), tanaman penghasil pakan untuk ternak lebah madu berupa tanaman alpokat, aren, asam, belimbing, bunga matahari, buah nona, cabe, delima, duku, durian, gamal, jagung, jambu biji, jambu air, jambu mete, jambu bol, jeruk bali, jarak, jati, kopi, karet dan berbagai jenis tanaman lainnya.

Penyebaran jenis tanaman pada lokasi-lokasi penelitian tidak merata, hal ini karena adanya penyediaan bibit tanaman, pengelolaan dan pemeliharaan tanaman atau perubahan status tanah dan sebagainya. Soerianegara dan Andry (1998), menyatakan bahwa penyebaran tanaman kebanyakan sebagai akibat aktivitas manusia di tempat itu seperti: perubahan hutan, pengolahan tanah dan penanaman tanaman yang berubah-ubah.

Sumber pakan lebah madu adalah tanaman yang meliputi tanaman buah-buahan, tanaman sayursayuran, tanaman hias, tanaman pangan dan perkebunan yang mengandung nektar dan pollen. Perubahan hutan, pengolahan tanah penanaman tanaman yang berubah-ubah membawa perubahan kimiawi dan alami dalam tanah dan mengakibatkan perubahan tanaman yang tumbuh. Tingkat perubahan jenis tanaman ini tergantung dari pada tipe tanah, intensitas pengolahan tanah, jenis tanaman di tempat itu dan cara budidaya tanaman. Selanjutnya tanaman penghasil pakan pun mengalami perubahan jenis dan jumlahnya pada suatu tempat atau pada musim tertentu, dari musim gagal bunga sampai musim berlimpah bunga.

Hasil pengamatan menunjukan bahwa pertumbuhan dan perkembangan lebah madu adalah sangat tergantung adanya tanaman penghasil pakan untuk kelangsungan hidupnya, karena sumber pakan lebah sebagian besar di hasilkan oleh tanaman. Saputra (2007) menyatakan hampir semua tanaman yang berbunga merupakan sumber pakan lebah madu. Pakan lebah madu adalah nektar dan pollen yang terdapat pada bunga dan air. Bunga dari tanamantanaman tersebut mengandung nektar dan pollen (tepung sari), (Adalina, 2008). Hasil pengamatan tidak semua jenis tanaman pada areal penggembalaan lebah madu itu sama, ada beberapa jenis tanaman yang tidak tumbuh atau tidak ada pada suatu areal penggembalaam lebah madu itu sama, namun tumbuh dan ada pada areal penggembalaan yang lain seperti jagung, gandaria dan alpokat. 
Tabel 1. Jenis-jenis tanaman pada areal pengembalaan lebah menurut lokasi penelitian

\begin{tabular}{|c|c|c|c|c|c|}
\hline & \multirow{2}{*}{ Jenis Tanaman } & \multicolumn{4}{|c|}{ Lokasi Peternakan Lebah } \\
\hline & & Kawatu & Hatusua & Waehatu & Kamaring \\
\hline Buah-buahan & $\begin{array}{l}\text { Mangga (Mangifera indica) } \\
\text { Langsat (Lansiu domesticium) } \\
\text { Pisang (Musa paradisiaca) } \\
\text { Jambu Biji (Psidium guajava) } \\
\text { Jambu Mete (Arnacidiu occidentale) } \\
\text { Jambu air (Syzgium aqueum) } \\
\text { Kwuini (Mangifera odorata) } \\
\text { Gandaria (Bouea macropaylla) } \\
\text { Alpukat (Persea americana) } \\
\text { Nangka (Artocarpus heterophyllus) } \\
\text { Kecapi (Sondoricium koetjtie) } \\
\text { Jeruk (Citrus aurantifolia) } \\
\text { Belimbing (Averroa carambola) } \\
\text { Rambutan (Nephelium Lappaceum) } \\
\text { Tomi-tomi (Nama local) }\end{array}$ & $\begin{array}{l}\sqrt{ } \\
\sqrt{ } \\
\sqrt{ } \\
\sqrt{ } \\
\sqrt{ }\end{array}$ & $\begin{array}{l}\sqrt{ } \\
\sqrt{ } \\
\sqrt{ } \\
\sqrt{ } \\
\sqrt{ } \\
\sqrt{ } \\
\sqrt{ } \\
\sqrt{ }\end{array}$ & $\begin{array}{l}\sqrt{ } \\
\sqrt{ } \\
\sqrt{ } \\
\sqrt{ } \\
\sqrt{ } \\
\sqrt{ } \\
\sqrt{ } \\
\sqrt{ } \\
\sqrt{ } \\
\sqrt{ }\end{array}$ & $\begin{array}{l}\sqrt{ } \\
\sqrt{ } \\
\sqrt{ } \\
\sqrt{ } \\
\sqrt{ } \\
\sqrt{ } \\
\sqrt{ }\end{array}$ \\
\hline Perkebunan & $\begin{array}{l}\text { Kakao (Theoproma cacao) } \\
\text { Kelapa (Cocos nufifera) } \\
\text { Cengkih (Syzygium aromaticum) } \\
\text { Pala(Myristisca fragranas houtt) } \\
\text { Aren (Arenga pinnato) } \\
\text { Kayu Nani }\end{array}$ & $\begin{array}{l}\sqrt{ } \\
\sqrt{ } \\
\sqrt{ } \\
\sqrt{ } \\
\sqrt{ } \\
\sqrt{ }\end{array}$ & $\begin{array}{l}\sqrt{ } \\
\sqrt{ } \\
\sqrt{ } \\
\sqrt{ } \\
\sqrt{ }\end{array}$ & $\begin{array}{l}\sqrt{ } \\
\sqrt{ } \\
\sqrt{ } \\
\sqrt{ } \\
\sqrt{ }\end{array}$ & $\begin{array}{l}\sqrt{ } \\
\sqrt{ } \\
\sqrt{ } \\
\sqrt{ } \\
\sqrt{ }\end{array}$ \\
\hline Hias & $\begin{array}{l}\text { Bunga Bougenvill } \\
\text { Bunga Komboja } \\
\text { Bunga Asoka }\end{array}$ & & $\sqrt{ }$ & $\begin{array}{l}\sqrt{ } \\
\sqrt{ } \\
\sqrt{ }\end{array}$ & \\
\hline
\end{tabular}

Tabel 2. Jenis-jenis tanaman penghasil nektar dan pollen pada lokasi penelitian

\begin{tabular}{|c|c|}
\hline Jenis Tanaman & Sumber nectar/polen \\
\hline $\begin{array}{ll}- & \text { Mangga (Mangifera indica) } \\
- & \text { Langsat (Lansiu domesticium) } \\
- & \text { Pisang (Musa paradisiaca) } \\
- & \text { Jambu Biji (Psidium guajava) } \\
- & \text { Jambu Mete (Arnacidiu occidentale) } \\
- & \text { Jambu air (Syzgium aqueum) } \\
- & \text { Kwuini (Mangifera odorata) } \\
- & \text { Gandaria (Bouea macropaylla) } \\
- & \text { Alpukat (Persea americana) } \\
- & \text { Nangka (Artocarpus heterophyllus) } \\
- & \text { Kecapi (Sondoricium koetjtie) } \\
- & \text { Jeruk (Citrus aurantifolia) } \\
- & \text { Belimbing (Averroa carambola) } \\
- & \text { Rambutan (Nephelium Lappaceum) } \\
- & \text { Tomi-tomi (Nama local) } \\
- & \text { Kakao (Theoproma cacao) } \\
- & \text { Kelapa (Cocos nufifera) } \\
- & \text { Cengkih (Syzygium aromaticum) } \\
- & \text { Pala(Myristisca fragranas houtt) } \\
- & \text { Aren (Arenga pinnato) } \\
- & \text { Bunga Bougenvill } \\
- & \text { Bunga Komboja } \\
- & \text { Bunga Asoka }\end{array}$ & $\begin{array}{l}\text { Nektar } \\
\text { Nektar } \\
\text { Nektar/polen } \\
\text { Nektar/polen } \\
\text { Nektar/polen } \\
\text { Nektar/polen } \\
\text { Nektar/polen } \\
\text { Nektar } \\
\text { Nektar } \\
\text { Nektar } \\
\text { Nektar } \\
\text { Nektar/polen } \\
\text { Nektar/polen } \\
\text { Nektar } \\
\text { Nektar/polen } \\
\text { Nektar } \\
\text { Nektar/polen } \\
\text { Nektar/polen } \\
\text { Nektar/polen } \\
\text { Nektar/polen } \\
\text { Nektar } \\
\text { Nektar } \\
\text { Nektar }\end{array}$ \\
\hline
\end{tabular}




\section{Kerapatan Populasi Tanaman}

Hasil perhitungan kerapatan dan frekwensi populasi tanaman pada masing-masing lokasi peternakan lebah madu di Kecamatan Kairatu sangat bervariasi. Hasil penelitian menunjukkan bahwa pada 4 Negeri sampel, jenis tanaman perkebunan seperti, mangga (Mangifera indica) dengan kerapatan 19,38\% dan ferkuensi $0,37 \%$, diikuti dengan tanaman kakao (Theoproma cacao) dengan kerapatan $16,88 \%$ dan ferkuensi 0,3\% lebih tinggi dibandingkan dengan jenis tanaman yang lain. Tingginya nilai kerapatan dan tingkat frekuensi disebabkan adanya program pemerintah dalam memberikan bibit-bibit tanaman terutama bibit tanaman mangga dan kakao, sehingga ditanam dibudidayakan oleh masyarakat di kecamatan Kairatu.

Jenis tanaman yang mempunyai nilai kerapatan dan tingkat frekwensi tinggi serta dalam keadaan berbunga akan dapat memberikan respon bagi lebah untuk mengunjungi. Agussalim dkk. (2017), mangga merupakan sumber nektar yang banyak ditemukan di areal perkebunan buah dan di pekarangan rumah. Mangga memiliki pola pembungaan musiman sehingga pada musim pembungaan banyak peternak lebah meletakan kotak di sekitar pepohonan mangga.

\section{Jenis-Jenis Tanaman Penghasil Nektar dan Pollen}

Hasil pengamatan terhadap jenis-jenis tanaman penghasil pollen yang dikunjung lebah madu pada masing-masing lokasi peternakan lebah madu dapat dilihat pada Tabel 2. Di Kecamatan Kairatu terdapat berbagai jenis tanaman dan tidak semua jenis tanaman yang ada di Kecamatan kairatu dikunjungi oleh lebah. Thomson dkk. (2017), lebah mempunyai kesukaan terhadap pollen tertentu. Apa alasannya belum diketahui pasti. Tetapi kesukaan mengumpulkan nektar adalah kerena kandungan zat- zat makanan yang terdapat di dalam nektar terutama kandungan gula.

Makin banyak nektar mengandung gula makin senang lebah mengunjungi bunga tersebut. Jenis tanaman yang sering dikunjungi lebah yakni tanaman yang sedang mangalami musim berbunga antara lain ; jambu mete, mangga, kakao, aren, jambu biji, jagung, kelapa, pisang, alpokat, rambutan dan pala. Pada umumnya semua tanaman berbunga merupakan sumber pakan bagi lebah, karena menghasilkan pollen dan nektar. Sihombing (2005), tanaman yang banyak menghasilkan pollen seperti jambu mete, mangga, kako, kelapa, aren, alpokat, rambutan, pala dan jambu biji. Jenis-jenis tanaman tersebut terdapat pada lokasi penelitian, disamping itu faktor yang paling menentukan daya tarik pollen bagi lebah adalah bau.

Tabel 3. Sisiran yang terisi bee bread menurut lokasi penelitian

\begin{tabular}{ccccc}
\hline No. Kotak (stup) & \multicolumn{4}{c}{ Lokasi Peternakan } \\
\cline { 2 - 5 } & Kawatu & Hatusua & Waehatu & Kamarian \\
\hline 1 & 5 & 3 & 2 & 4 \\
2 & 3 & 4 & 3 & 4 \\
3 & 4 & 6 & 5 & 3 \\
4 & 2 & 4 & 4 & 5 \\
5 & 5 & 5 & 2 & 6 \\
6 & 3 & 3 & 3 & 3 \\
7 & 4 & 4 & 2 & 5 \\
8 & 3 & 3 & 4 & 4 \\
9 & 5 & 2 & 5 & 3 \\
10 & 2 & 4 & 2 & 41 \\
\hline Jumlah & 36 & 38 & 32 & 4.1 \\
\hline Rata-rata & 3.6 & 3.8 & 3.2 & \\
\hline
\end{tabular}

\section{Jumlah Sisiran Yang Terisi Bee Bread}

Jumlah sisiran yang terisi bee bread untuk tiap kotak pada masing-masing lokasi pengembalaan lebah seperti tertera pada Tabel 3. Usaha beternak lebah madu yang dilakukan pada keempat negeri sampel menggunakan sepuluh (10) kotak yang masing-masing kotak terisi tujuh sisiran. Hasil penelitian menunjukan bahwa tidak semua sisiran pada kotak terdapat bee bread. Dari ke empat desa/negeri sampel, negeri yang memiliki jumlah sisiran yang terisi bee bread terbanyak adalah Negeri Kamariang dengan jumlah 41 sisiran, Negeri Hatusua 38 sisiran, Dusun Kawatu 36 sisiran dan Negeri Waehatu 32 sisiran. Negeri Kamaring mempunyai jumlah sisiran terbanyak yang terisi oleh bee bread disebabkan kerena tanaman penghasil pollen banyak dan tanaman-tanaman tersebut dalam keadaan berbunga.

Banyaknya jumlah sisiran yang terisi bee bread tergantung pada tanaman pakan lebah dan kepadatan tanaman dan musim berbunga karena bau yang 
dikeluarkan oleh tanaman dapat membuat lebah menyinggahi tanaman itu. Sihombing (2005), menyatakan bahwa pengaruh faktor lingkungan terhadap intensitas pengumpulan pollen dapat terjadi secara langsung atau tidak langsung. Secara langsung dapat berupa pengaruh terhadap aktifitas terbang, tingkat atau pola konsumsi makan, secara tidak langsung dapat melalui tingkat produksi pollen bunga. Temperatur lingkungan sangat mempengaruhi jumlah konsumsi makan lebah madu dan dengan demikian akan mempengaruhi tingkat pengumpulan bahan makanan (pollen dan nektar) dari lapangan. Di samping itu kelembaban, temperatur, kecepatan angin dan intensitas cahaya berpengaruh terhadap pengambilan pollen.

Pollen yang diambil oleh lebah akan diletakan di dalam sisiran-sisiran yang terdapat dalam kotak lebah. Kepadatan tanaman juga berpengaruh karena semakin banyak tanaman yang berbunga, lebah akan memperoleh pakan yang banyak. Sihombing (2005) menyatakan bahwa sewaktu mengumpulkan pollen seekor lebah pekerja harus mengunjungi banyak bunga umumnya sekitar 50-1000 bunga. Proses pembentukan pollen berlangsung secara berangsur-angsur dan sangat tergantung dari tersedianya flora pakan penghasil pollen dalam jumlah yang banyak.

\section{SIMPULAN}

Berdasarkan hasil dan pembahasan yang dikemukakan, maka dapat ditarik kesimpulan (1) jenis tanaman yang terdapat pada empat lokasi peternakan lebah madu adalah tanaman perkebunan seperti kelapa, kakao, pala, cengkih dan aren ; (2) jenis tanaman yang memiliki nilai kerapatan dan frekuensi tertinggi adalah tanaman kakao, jambu biji, aren dan mangga ; (3) jenis-jenis tanaman penghasil pollen yang disukai dan dikunjungi oleh lebah madu adalah tanaman perkebunan yaitu: kelapa, aren, kakao dan jambu mete ; dan (4) lokasi peternakan lebah madu yang memiliki jumlah sisiran terbanyak terisi bee bread adalah Negeri Kamarian sedangkan terendah adalah Negeri Waehatu.

\section{DAFTAR PUSTAKA}

Adalina, Y. 2008. Analisis Finensial Usaha Lebah Madu. Jurnal Penelitian Hutan dan Konservasi Alam. 5(3):217-237.

Setiawan, A., R. Sulaeman, dan T. Arlina. 2016. Strategis Pengembangan Usaha Lebah Madu Kelompok Tani Setia Jaya. Desa Kembal Jaya Kecamatan Bangun Purba Kabupaten Rokan Hulu. Jurnal Online Mahasiswa (JOM) Faperta. 3(1):1-9.

Agussalim, A. Agus, N. Umami, dan I. G. S. Budisatria. 2017. Variasi Jenis Tanaman Pakan Madu Sumber Nektar dan Polen Berdasarkan Ketinggian Tempat Di Yogyakarta. Buletin Peternakan. 41(4):448460.

Arifin, A. 1994. Hutan Hakekat dan Pengaruhnya Terhadap Lingkungan. Jakarta: Yayasan Obor Indonesia.

Lamerkabel, J. S. A. 2010. Perkembangan Lebah Madu di Provinsi Maluku. Makalah disampaikan pada musyawara nasional Asosiasi Pelebahan Indonesia. Cibubur.

Saputra. 2007. Pemeliharaan Lebah Madu Jurnal com/2013/11. [20/08/2019].

Sihombing. 2005. Ilmu Ternak Lebah Madu. Yogyakarta: Gajah Mada University Press.

Soerianegara, I., dan I. Andry. 1998. Ekologi Hutan Indonesia, Laboratorium Ekologi Hutan. Bogor: Fakultas Kehutanan, Institut Pertanian Bogor.

Thomsom, S., Salmiah dan F.A. Sri. 2017. Budidaya Ternak Lebah Di Desa Sumberrejo Kecamatan Marbau Kabupaten Deli Serdang. Abdfimas Talenta. 2(2). http//jurnal usu.ne.id/abdimas. [20/08/2019].

Walji, H. 2001. Terapi Lebah Daya Kekuatan dan Khasiat, Lebah Madu dan Serbuk Sari, Jakarta: Prestasi Pustaka. 